\title{
Social work education: Reflections during Covid-19 lockdown
}

Kelly J. Glubb-Smith, Lecturer, University of Waikato

Tania Roberts, BSW Student, University of Waikato

Teaching social work students in Aotearoa New Zealand during the Covid-19 crisis produced an acute awareness of the impact of lockdown levels 3 and $4{ }^{\mathrm{i}}$ on student wellbeing. Students were required to rapidly adapt to study in a fully online environment without the face-to-face support of university campus life. Normal social and academic pressures were immediately intensified, with no immediate relief in sight. Student resilience was tested further due to multiple factors such as: suddenly reduced incomes, parenting during lockdown, caring for whānau both within and external to their "bubble" ii, and being unable to come together with loved ones to celebrate life events or mourn those who had passed.

Through interactions with social work students during the Covid-19 lockdown it was evident that whannau was frequently their priority, and for those who were parents, the demands of home-schooling and the needs of their whānau became all consuming. The struggle of balancing these competing commitments was significant and, when checking on who had access to the internet for example, or a device to work on, or exploring why extensions for assignments were necessary, academic staff were offered a bigger-than-usual window into the lives of their students.

Social work educators have long recognised the many challenges facing social work students. Conversations between lecturers during this time reflected on the changing experience of university studies in Aotearoa New Zealand. For example, in the 1980s and early 1990s, there was access to a relatively healthy state-funded student allowance and low course fees; in comparison, students enrolled in tertiary studies in 2020 live with high-cost housing and student loan debt. As mentioned above, many of them have the primary responsibility for children and therefore balance the demands of parenting with a reduced income because of their social work studies. Covid-19 disruptions have added precarious layers of adversity into the lives of many.

In addition to the well-being of students during the Covid-19 lockdown, the logistics of field education were a considerable concern for social work educators, with uncertainty related to the conditions of the various levels of lockdown, and when they would occur. This concern was undoubtedly experienced by students. Despite the above, however, and how insurmountable the challenges must have felt for many students, the lecturers did observe high levels of resilience. Many social work students have historically had a tangible sense of security through being in a tight-knit community of face-to-face learners. They are still adapting to being separated and connecting online to create a virtual community of learners.

Critical reflections are set as assignments for University of Waikato social work students and, during the Covid-19 lockdown, these served as another window into the students' values and coping mechanisms. The students were required to critically analyse allocated readings against their burgeoning knowledge of social work practice, and their writing often included pertinent observations of the societal disruptions produced by Covid-19. The experiences of students during Covid-19 lockdown tell a 
story of shared trauma through disruption and struggles to be resilient in their studies. The critical reflections written by students under Covid-19 lockdown conditions were rich and varied. Combined, they add to a kete of knowledge about recognising and responding to unprecedented stress and adversity, alongside their belief in the power of community to care for each other.

As an example, the reflection below by fourth-year student Tania Roberts, applies Te Ao Māori concepts of collective identity, of rāhui, tapu, noa and pā whakawairua to the Covid-19 situation. Tania's framing of the pandemic response is informed by her standing in the world, that of a Māori social work student (Ngāti Kirihika, Raukawa) who is close to degree completion, having worked previously within social services. Like many social work students, Tania juggles study with parenting young children and other community commitments.

\section{Tania Roberts}

This critical reflection focuses on how concepts of tapu and noa, and the differences between Western individualised perspectives and Māori collective perspectives, help to make meaning of what is happening during the current situation of the Covid-19 lockdown.

Quince (2010) identifies the concept of tapu as linked to privacy, and related to things that are restricted, including people, places and objects. One similarity between Māori and $P \bar{a} k e h \bar{a}$ ideas of privacy is described by Quince (2010) as the desire to protect people. This concept is relevant to our current situation where the people of Aotearoa New Zealand are all remaining within the walls of their own homes, maintaining social distance from one another with the intention of protecting themselves, their families, the country of Aotearoa New Zealand and the world from Covid-19.

An individualised perspective of this situation could be one where the Covid-19 lockdown is viewed as something to make us stay at home, to be stuck inside. For younger, more healthy people there may be thoughts of "Why should I stay home if this virus won't kill me?" The panic buying also displayed some individualised behaviour where people have stocked up on items out of fear they will run out; the effect of this being that others have missed out. For example, I have heard stories of people buying entire freezers to fill up, leaving no affordable products left for those who barely survive week-to-week.

However, if we were to view the lockdown from a traditional Māori collective perspective, the whole experience of the Covid-19 lockdown could be changed. Quince (2010) describes the Māori concept of rāhui as a ban or seasonal tapu that can be temporarily imposed for the protection of the environment and its people. The collective mana of the people is dependent on the efforts they make in recognising and preserving this tapu (Quince, 2010). So, instead of the perspective: "This lockdown means I am stuck at home and have no choice about it," we could view it as a rāhui: "By staying home I am keeping myself and others safe, and I am also protecting the environment and giving it a chance to heal."

Ruwhiu, Te Hira, Eruera, and Elkington (2016) describe Māori concepts of $p \bar{a}$ whakawairua which are also relevant to our current reality. The traditional concept of $p \bar{a}$ is described as a protected haven of safety and refuge and whakawairua is described as replenishing, refilling and strengthening (Ruwhiu et al., 2016). Therefore, the current Covid-19 lockdown or rāhui could be seen as an opportunity for us all to retreat into our homes, which one would hope are our safe places where we can recharge alongside our whānau and remain protected from the invisible threat that is outside (the Covid-19 virus). Also, once the virus has been defeated, tapu will be lifted and we will be placed back into a state of noa or normality.

Another traditional Māori concept relevant to the current situation is the perspective 
that our elders are taonga, to be respected and nurtured. Ruwhiu et al. (2016) describe elders as leaders who model lessons and behaviour for future generations to follow. Therefore, instead of perspectives such as: "I am healthy and less likely to get sick from the virus, so why should I have to stay home?" a person could, instead, think: "We are the kaitiaki of our elders, this virus seems to impact them the most and by choosing to stay at home I could be saving their lives."

Social work education is a journey into understanding structural forces that impact upon individuals and communities. Those in the helping professions, such as social workers, are used as a resource in their whānau and communities as a source of sound, pragmatic advice. The same appeared to be true for social work students during lockdown. Due to the emphasis they place on social inclusion, social work students often acted as kaitiaki, responding to the needs of those around them and recognising and responding to social justice issues in their day-to-day lives. Examples of this were reported in on-line class conversations, of instances of opening their homes to people in need prior to lockdown, hours spent caring for whānau outside of their bubble, helping neighbours or preparing food for people who were homeless.

\section{Notes}

i In March 2020 the New Zealand Government announced four levels of alert for the Covid-19 pandemic. These levels specified the actions required and Level 4 was the highest. https://covid19.govt.nz/covid-19/restrictions/ alert-system-overview/

ii The term 'bubble' was used in New Zealand to denote the group of people within a dwelling with whom social distancing was not required during the Level 3 and 4 lockdowns.

\section{References}

Quince, K. (2010). Māori concepts and privacy. In S. Penk \& R. Tobin (Eds.), Privacy law in New Zealand (pp. 27-48). Brookers.

Ruwhiu, L. A., Te Hira, L., Eruera, M., \& Elkington, J. (2016). Borderland engagements in Aotearoa New Zealand: Te Tiriti and social policy. In J. Maidment \& L. Beddoe (Eds.), Social policy for social work and human services in Aotearoa New Zealand: Diverse perspectives (pp. 79-93).: Canterbury University Press. 